\title{
GRAMMATICAL ERRORS COMMITED BY EIGHT GRADE STUDENTS IN WRITING RECOUNT TEXT
}

\author{
Fridayanthi, N.P.T.M.E. \\ English Language Education, Faculty of Language and Art \\ Universitas Pendidikan Ganesha \\ Singaraja, Indonesia \\ martya_ersa@yahoo.com
}

\begin{abstract}
There are 2 purposes of conducting this study, (1) finding the errors commonly made in writing recount text by eighth grades students at SMPN 2 Seririt; and (2) finding the sources of the errors committed in writing recount text by eighth grades students at SMPN 2 Seririt. As a descriptive qualitative research, there were two main instruments used in this study, they were the researcher and the sample of writing. After gaining the data, then descriptive analysis was conducted. From 30 students' writing which were analyzed based on surface strategy taxonomy proposed by Dulay et al. (1982), it is found that there are 169 errors committed by the subject including $130(77 \%)$ omission errors, $14(8.28 \%)$ misordering errors, $13(7.7 \%)$ misformation errors, and 12 (7.1\%) addition errors. Omission error becomes the most frequent errors committed by the students. There are three types of errors sources found in this study, those are intralingual transfer (90.96\%), interlingual transfer (7.22\%), and context of learning (1.8\%).
\end{abstract}

Keyword: error analysis, grammatical error, recount text

\section{INTRODUCTION}

Writing is defined as complex process which demands cognitive analysis and linguistics syntheses (Tan as cited in Afifuddin, 2016). In learning writing, the learners are supposed to express their idea, feelings, thought, and also their opinion. According to Ghaith as cited in Sahara (2017), writing in English is not easy and some students will find out the difficulties while they write. The students can face the difficulties in writing because they have lack of vocabulary, spelling the word, grammar rules, and practice in writing. According to Brown (1980), writing is the process of putting ideas on a paper to change our thought into words, to sharpen our main ideas, to give them structure and coherent organization. Writing is a task which involves the students to make correct sentences grammatically by manipulating words in the form of a piece of continuous writing with successfully communicates the writers' ideas on a certain topic (Heaton, 1975: 127).

Based on the observation conducted by the researcher, it was found that the students still committed errors, for example, the student wrote "After we arrive to the beach, we visited a villa". Based on the sentence that made by the students, there was an error in that sentence. In that sentence, there is a word "arrive", it was an error because the student did not put a marker $\mathrm{d} / \mathrm{ed}$ to make a past tense in that sentence. It relates with one type of error based on Dulay's theory, it is omission of marker. So, the sentence should be "After we arrived to the beach, we visited a villa." In this study, the researcher used some previous studies in which had same topic, those were Purnayati (2015) and Nitiadhi (2016). Those studies conducted such a study in which the data were collected through project and for the sources of errors were explained based on the interview with the subject. Besides, the model of error analysis used in this study was different from previous studies. It was hoped that the result of this study could give contribution to the development of English teaching and learning.

In writing, there are some types of text; descriptive text, narrative text, exposition text, recount text, etc. As one type of text which should be learned in writing, recount text is reconstruction of something which happened in the past (Djuharie as cited in Ramli (2013). 
Recount text is the text that tells about the events or the experiences in the past in which this kind of text is used to entertain the audiences (Derewianka as cited in Cholipah, 2014). The purpose of recount text is to entertain the readers. In recount text, the writers will begin with telling the readers about what happened, who involved in the story, when and where the events occurred and why it can be happened. In recount text, simple past tense is used to tell the story by the writer.

The generic structures of recount text, such as orientation, sequence of events, re-orientation. Orientation in recount text provides the background information to make sense of the text for the audience (Hyland as cited in Azhar, 2015).

According to Greenbaum and Nelson (2002), grammar is the set of rules that allows us to combine words in our language into larger units. Grammar is a part of the language that should be mastered by the learner. By learning grammar, the learner can produce the sentences correctly. Besides that, grammar is the way a language use and combine the words in order to form longer units of meaning (Penny Ur, 1988). Grammar is a word that puts together to make a correct sentence. It is not only affect how the unit of the word are combined, but it affects the meaning too.

According to Dulay, Burt, and Krashen (1982), errors are deformed side of the learner speech of writing. Errors are the part of conversation or the composition that deviate from some selected norm of mature language performance. Making errors is an inevitable part of learning. In learning the language, people cannot learn the language without making errors. On the other hand, error is a part of systematic study of the learners' language which needs to understand the process of the second language acquisition (Corder, 1981 as cited in Evayani, 2013). According to Brown (1983), mistake is an error performance that is either a random guess or a "slip", means that mistake is a failure to utilize a known a system correctly. All of the people can make mistakes in their native and also in their second language situations. Some people think that error and mistake are the same. Some people have overlapping perception between error and mistake. Error and mistake will give negative impact to the students to know and to measure their competence in learning process if error and mistake are treated inappropriately.

Error analysis is the process of determining the incidence, nature, causes, and the consequences of unsuccessful the language (James, 1998). Another explanation from expert about error analysis is according to Dulay, Burt, and Krashen (1982), error analysis has produce the insights into the second language acquisition process that have stimulated the major changes in teaching practice. It is controversial contribution that has been discovery that the majority of grammatical errors of second language learners made do not reflect their mother tongue, but the young children made as they learn their first language. It seems like first language learners' error, the most of the error in second language made by the learners indicate that they are slowly building the second language rule system.

According to Dulay, Burt, and Krashen (1982), there are four types of errors. Those are linguistic category taxonomy, surface strategy taxonomy, comparative taxonomy, and communicative effect taxonomy. Linguistic category taxonomy classifies errors according to the language component which includes phonology (pronunciation), syntax and morphology (grammar), semantic and lexicon (meaning and vocabulary), and discourse (style), and constituents which includes the elements that comprise each language component. Surface strategy taxonomy points that the way surface structure are changed. The learners may have to omit necessary items and add unnecessary ones, they may misform and misorder the items. Hence, Dulay et al divided the error based on surface strategy taxonomy into four categories, namely omission, addition, misformation, and misordering. Comparative taxonomy is based on comparison between the structure of second language errors and certain other types of constructions. Communicative effect taxonomy deal with errors from perspective of their effect on the listener or reader. Based on those types of errors, in this study the researcher will conduct the data by using the second taxonomy from Dulay et al (1982), surface strategy taxonomy. This taxonomy is chosen because the errors based on this taxonomy are very often made by the learners. Types of errors based on surface strategy taxonomy are omission, addition, misformation, and misordering. Omission errors are characterized by the absence of an item which must arise in well-formed sentence. In omission, there two types of morphemes in a sentence, such as grammar morphemes and content morphemes. In grammar morphemes include preposition, article, to be, conjunction, and marker. 
However, addition errors are the opposite of omission errors. Addition errors are characterized by the presence of the item which must not arise in well-formed structure. In addition errors, there are three types of addition, namely double marking, regularization, and simple addition.

Misformation errors are the use of wrong form of morpheme or structure. In misformation errors, the learners supply something, although it is incorrect. There are types of misformation, namely regularization, archi form, and alternating form.

Misordering errors refer to the wrong placement of a morpheme or a group of morphemes in an utterance.

According to Brown (1980), there are four sources of errors, namely interlingual transfer, intralingual transfer, context of learning, and communication strategies. Interlingual transfer is the negative interference of first language. Sometimes, the learners use the linguistic system of their first language in making target language sentences. Identifying an error caused by interlingual transfer can be done by translating the sentence that made by the learners from the target language into their first language.

However, Intralingual transfer is the negative transfer of items within the target language itself. In intralingual transfer, there are several types, namely overgeneralization, ignorance of rule restriction, incomplete application of rules, and false concepts hypothesized. Context of learning refers to the source of errors that come from the outside. Context refers to the classroom with the teacher and the material. The teacher or textbook can lead the learners to make incorrect hypotheses about the language. Because of a misleading from the teacher, the learner can make errors. Communication strategies is related with learning style. Communication strategies is strategy that conducted by the learners to be able to communicate in the target language although they have not mastered yet the needed competence of the target language.

Considering the explanation above, the purposes of this study are (1) find out the errors are commonly made in writing recount text by eighth grades students at SMPN 2 Seririt and (2) to find out the sources of errors committed in writing recount text by eighth grade students at SMP N 2 Seririt. It is important to know the errors committed by the students in writing in order to increase their quality in writing. Teachers need to give more chance to the students to practice their skill because by practicing students can make reflection and also can make their writing skill better.

\section{METHODS}

This study was a descriptive qualitative study which was conducted at SMPN 2 Seririt. The subject of this study was VIII A class of the eighth grade students at SMPN 2 Seririt. The object of this study was the eighth grade students' writing at SMPN 2 Seririt. According to Gass and Selinker (2008), there are some procedures of error analysis, those are collecting data, identifying errors, classifying errors, quantifying errors, analyzing source, and remediate.

\section{RESULT AND DISCUSSION}

Based on the previous results, the frequency and percentage of each types of errors committed by the students can be seen in table 1 
Table 1 The Frequency and Percentage of Each Type of Errors

\begin{tabular}{|c|c|c|c|c|c|c|c|c|c|c|c|c|c|c|}
\hline \multirow{3}{*}{ No } & \multicolumn{14}{|c|}{ Types of Errors } \\
\hline & \multicolumn{6}{|c|}{ Omission } & \multicolumn{4}{|c|}{ Addition } & \multicolumn{3}{|c|}{ Misformation } & \multirow{2}{*}{$\begin{array}{l}\text { Misorde } \\
\text { ring }\end{array}$} \\
\hline & $\begin{array}{l}\text { OPre } \\
\mathrm{p}\end{array}$ & $\begin{array}{l}\mathrm{O} \\
\mathrm{A}\end{array}$ & $\begin{array}{l}\mathrm{O} \\
\mathrm{T}\end{array}$ & OCon & $\mathrm{OM}$ & $\mathrm{OV}$ & $\begin{array}{l}\mathrm{O} \\
\text { Pro }\end{array}$ & $\begin{array}{l}\mathrm{D} \\
\mathrm{M}\end{array}$ & Reg & $\begin{array}{l}\mathrm{S} \\
\mathrm{A}\end{array}$ & $\begin{array}{l}\text { Misf } \\
\text { Reg }\end{array}$ & $\mathrm{AF}$ & $\mathrm{AlF}$ & \\
\hline Frequency & 8 & 16 & 33 & 2 & 64 & 4 & 3 & 3 & 3 & 6 & 8 & 0 & 5 & 14 \\
\hline \multirow[t]{2}{*}{ Total } & & & & 130 & & & & & 12 & & & 13 & & 14 \\
\hline & & & & $(77 \%)$ & & & & & $(7.1 \%$ & & & $(7.7 \%)$ & & $(8.28 \%)$ \\
\hline
\end{tabular}

From table 1, it can be seen that the most frequent error committed by the subject was omission error. There were 130 omission errors found the recount text composed by the subject and the percentage was $77 \%$. The second most frequent was misordering error. There were 14 errors in misordering error and the percentage was $8.28 \%$. The third most frequent was misformation. There were 13 errors in misformation error and the percentage was $7.7 \%$. The last frequent type of errors was addition. The subject committed 12 errors of this type and the percentage was $7.1 \%$. The following is an example of each type of erros.

Omission: I visit my uncle house.

The sentence was incorrect sentence because of the use of wrong choice of verb form. The sentence was in simple past tense, so the correct verb form is past tense verb. The correct sentence is "I visited my uncle house."

Misordering: I and my cousin went to the pasir putih Pejarakan.

The previous example was incorrect sentence because in English it is common to say "my cousin and I" instead of "I and my cousin". The correct sentence is "My cousin and I went to the pasir putih Pejarakan."

Misformation: I spend my holiday in Denpasar.

The sentence was incorrect because of the use of incorrect form of verb. The correct sentence is "I spent my holiday in Denpasar."

Addition: I did not went anywhere.

The auxiliary used to form a negative past tense sentence is did + not and followed by bare infinitive. From those sentences, it can be seen that "did + not" was followed by past tense verb. Both the auxiliary did and the past tense verb marked the same thing that is, the activity that happened in the past. The correct sentence is "I did not go anywhere."

Contrast with this finding, the studies conduct by Amalia (2013), Purnayati (2015), and nitiadhi (2016) found that the most frequent errors of their study was misformation errors. The study conducted by Amalia (2013) found that there were 140 errors of misformation errors and the percentage was 56\%. In Amalia's study, misformation errors was the highest error committed by the students because the students still had no mastered in the use of past tense.

Purnayati (2015) found that there were 50 errors of misformation errors and the percentage was 29.94\%. In Purnayati's study misformation errors as the highest error committed by the students because of the wrong choice of verb forms. Based on her study, the students still had difficulty in deciding whether to use bare infinitive, to infinitive, present participle form of verbs, past tense form of verb, etc. the students thought that all verbs in recount text should be written in past tense form. For example, the student made a sentence "My second sister sited beside my first sister". It was incorrect sentence because the word "sit" is irregular verb. It does not take marker -ed/-d to make the past tense forms. The word "sited" should be changed into "sat". 
The study conducted by Nitiadhi (2016) found that there were 147 errors of misformation errors and the percentage was $44.96 \%$. Based on her study, many students committed misformation error in writing English because the students used incorrect verb. For example, the student made a sentence "I goed to Denpasar", it was incorrect because the student added suffix -ed in the sentences for stating regular verb of "go".

Meanwhile the right verb of the word "go" in the past is "went". It can be said that the student used incorrect regular marker to the irregular verb of "go". The word "goed" should be changed into "went". Besides that, the misformation error can be happened in Nitiadhi's study because the use of incorrect sentences in term of using past tense. In writing recount text which tells about past, it should use past tense. However, many students still use present tense in writing recount text. In general, omission errors found in this study were omission of marker. In English, there are several markers, such as suffix -ed/-d to form past tense verb, -es/-s to form plural nouns, etc. The subject of this study still had difficulty to put marker where it is needed. All of the sentences were containing errors which were found in the descriptive text produced by VII C students at SMP N 2 Seririt were analyzed to find the sources of the errors committed. From students' writing, there are three sources of errors found in this study. Those are, interlingual transfer, intralingual transfer, and context of learning.

From the result, it can be seen that the most frequent source of errors is intralingual transfer, after that interlingual transfer, and the last is context of learning. Intralingual transfer is the negative transfer of items within the target language itself. It is the incorrect application of within the target language. All types of intralingual transfer found in this study. The total numbers of errors caused by intralingual transfer were 151 errors and the percentage was $90.96 \%$. There were 8 errors caused by overgeneralization, 71 errors caused by ignorance of rule restriction, 64 errors caused by incomplete application of rules, and 8 errors caused by false concepts hypothesized.

Interlingual transfer is the negative interference of first language. Sometimes, the learners use the linguistic system of their first language in making target language sentences. Identifying an error caused by interlingual transfer can be done by translating the sentence that made by the learners from the target language into their first language. There were 12 errors found in this study and the percentage as $7.22 \%$.

Context of learning refers to the source of that come from the outside. Context refers to the classroom with the teacher and the material. The teacher or textbook can lead the learners to make incorrect hypotheses about the language. Because of misleading from the teacher, the learner can make errors.

In this study, there were 3 errors found which were caused by context of learning and the percentage was $1.8 \%$. This finding is similar with the previous researchers in which the most frequent source of errors was intralingual transfer. Purnayati (2015) found that intralingual transfer had the highest percentage compared to other sources of errors that was $54.45 \%$. Based on Purnayati's study shows that many students thought that the verbs used in recount text were always in past tense form since recount text tells a story which happened in the past. For example, the student made a sentence "We didn't forgot to take pictures". It was incorrect because the student did not use the correct verb form. Verb of senses are followed by object + bare infinitive or present participle form of verbs. The sentence "We didn't forgot to take pictures" should be changed into "We didn't forget to take pictures".

This finding was also supported by the findings by Nitiadhi (2016). She found that intralingual transfer caused her subjects to make many errors. The percentage was $52.29 \%$. Based on Nitiadhi's study, intralingual transfer as the highest source of errors committed by the students because the lack motivation of the students in learning English. For example, “.....bought many thing", “.... after bought some fruit", "I meet a my friends". From those sentences, we can see that those sentences were influenced by the students" carelessness in writing. From those sentences, the students omitted the pluralization "s" in the words "fruit" and "thing", besides that the student added English article "a" in the sentence. From those examples, it can be said that the students put lack of attention in writing those sentences where they did not realize the use of pluralization well.

Intralingual transfer was the major source of errors found in this study. Intralingual transfer refers to the errors which are caused by the complexity of the target language itself. There are four kinds of 
intralingual transfer, namely overgeneralization, ignorance of rule restriction, incomplete application of rules, and false concept hypothesized. Those four kinds of intralingual transfer found in this study. The most frequent of intralingual transfer causing the errors committed by the subject of this study was ignorance of rule restriction. Many students failed in observing the restrictions of existing structures. It is the wrong application of rules to context in which they do not apply.

\section{CONCLUSION}

After analyzing students' writing, the researcher found that there were four types of errors. Those were omission, addition, misformation, and misordering. There were seven types of omission errors found in this study, namely omission of preposition, omission of article, omission of to be, omission of conjunction, omission of marker, omission of verb, and omission of pronoun. In addition errors, there were three types of addition errors found in this study, namely double marking, regularization and simple addition. There were two types of misformation errors found in this study, namely regularization and alternating form and also there were misordering errors found in this study.

Regarding the sources which caused students' errors, there were three sources of errors found in this study. Those were intralingual transfer, interlingual transfer, and context of learning. There were four types of intralingual transfer found in this study, namely ignorance of rule restriction, incomplete application of rules, overgeneralization, and false concept hypothesized.

In connection with the conclusion stated previously, the researcher would like to propose suggestions. For the teachers, they should be more aware and sensitive of students' difficulties in mastering English. The teacher also should use an innovative way of teaching English grammar. Further, the teacher needs to give more exercises related to English grammar while writing certain kind of text. For the students, in learning English, students are expected to be creative and innovative. Students also need to practice more to be able to master English. They can try to write their feelings or opinions in English even though they are not assigned by the teachers. From their writing, they can correct their product as well as their friends' product.

\section{REFERENCES}

Afifuddin. (2016). An Analysis Of Students' Error In Writing Descriptive Texts. English Education Journal, 7(1), 130-139.

Agustina, T. (2016). Error Analysis In Writing Recount Text By The Eighth Grade Students Of Smp Muhammadiyah 4 Surakarta Academic Year Of 2015/2016.

Amalia, N. (2013). An Error Analysis of Students' Writing on Recount Text (A Study at Eleventh Year Students of SMA Negeri 2 Banda Aceh). Syah Kuala University.

Azhar, S. (2013). Analysis of generic structure of recount texts (The Study of Fourth Semester Students of STAIN Salatiga in the Academic Year of 2012/2013). State Institute For Islamic Studies (IAIN) Salatiga.

Beard, A., Ridge, K., \& Mcchleery, E. (2003). A Routledge Level English Guides: How Texts Work. London.

Brown, H. D. (1980). Principles of Language Learning and Teaching.

Cholipah. (2014). An Analysis of Students 'Error in Writing Recount Text ((A Case Study in the Second Grade Students of SMP Trimulia Jakarta Selatan). Syarif Hidayatullah State Islamic University.

Dewanti, A. (2007). An Analysis of Grammatical Errors in Writing Narrative Texts Done By the Second Semester Students at the Diploma Program English Department in Airlangga University Surabaya. Universitas Airlangga.

Dulay, H., Burt, M., \& Krashen, S. (1982). Language two. New York: Oxford University Press. 
Evayani. (2013). An Analysis On Grammatical Errors In Students' Recount Text Writing (A Case Study at the Second Grade Students of MAN 10 Jakarta). Syarif Hidayatullah State Islamic University.

Gass, S. M., \& Selinker, L. (2008). Second Language Acquisition: An Introductory Course, Third Edition. New York.

Greenbaum Sidney, \& Nelson Gerald. (2002). An Introduction To Englsih Grammar (Second). London.

Harris, A., Ansyar, M., \& Radjab, D. (2014). An Analysis Of Students' Difficulties In Writing Recount Text At Tenth Grade Of SMA N 1 Sunga Limau. English Language Teaching Journal, 2(1).

Herlinawati. (2011). Error Analysis in The Students Writing Narrative Paragraph at MTsN Pajajaran Pamulang. State Islamic University.

Khalifa, M. (2017). A Contrastive Metrical Analysis of Main Word Stress in English and Cairene Colloquial Arabic (p. 44). Cambridge Scholars.

Mulyaningsih, D. U. (2013). An Analysis of Students' Ability in Writing Narrative Texts (A Case study at One Public Junior High Schools in Bandung). Journal of English and Education, 1(2).

Nitiadhi, N. N. (2016). An Analysis of Grammatical Errors Committed By The Tenth Grade Students of SMA Negeri 2 Banjar In Writing Recount Texts, In Academic Year 2015/2016.

Noviani, A. (2015). An Error Analysis on Students' Recount Text. Syarif Hidayatullah State Islamic University.

Novita, S. (2017). Common Grammatical Errors In Writing Narrative Text of Eighth Grade Students at MTs Negeri Sijenjang, 1-11.

Nurhayati, I. (2015). Journal of English Language Teaching Interlanguage: Grammatical Errors On Students 'Recount Texts ( A Case Study of First Year of MAN 2 Banjarnegara, 4(1). Retrieved from http://journal.unnes.ac.id/sju/index.php/elt

Nurohmah, I. (2013). An Analysis of Students ' Recount Text by Using Systemic Functional Grammar, 1(2), 89-98.

Purnayatri, L. A. (2015). An Analysis of Grammatical Errors Committed By The Tenth Grade Students of SMA Negeri 1 Baturiti In Writing Recount Text In Academic Year 2014/2015.

Putri, P. S., \& Dewanti, A. (2014). An Analysis of Grammatical Errors in Writing Narrative Texts Done, 03(01).

Ramli, D. (2013). An Analysis on Students 'Errors in Writing Recount Text. Tanjungpura University.

Rattanadilok Na Phuket, \& Normah Othman. (2015). Understanding EFL Students' Errors in Writing. Journal of Education and Practice, 6(32).

S, I. P. (2016). Improving Students' Writing Skills Of Analytical Exposition Text Through Mind Mapping Strategy At The Second Grade Of SMAN 9 Bandar Lampung. University of Lampung.

Sri, S. (2016). The Use Of Cohesive Devices In Students' Writing. Lampung University.

Ur, P. (2009). Teaching Grammar: Research, Theory And Practice.

Utami, T. A. A. (2014). Improving the Alibity in Writing Descriptive Texts Through Brainstorming Technique for Grade VIII Students at SMP N 1 Piyungan. Yogyakarta State University.

Wahyuni, Mahrum, M., \& Muhsin. (2014). Analyzing Errors Made By The Grade VIII Students in 
Writing Recount Text, 2(3).

Watcharapunyawong, S., \& Usaha, S. (2013). Thai EFL students' writing errors in different text types:

The interference of the first language. English Language Teaching, 6(1). https://doi.org/10.5539/elt.v6n1p67 